\title{
Evaluation of Dredged Material Proposed for Ocean Disposal from Hackensack River Project Area, New York
}

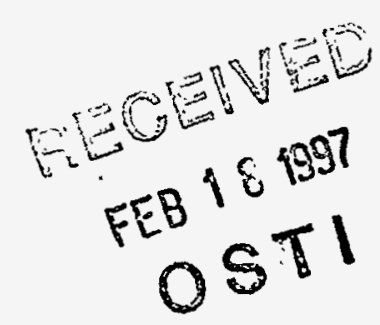

B. D. Gruendell

E. S. Barrows

A. B. Borde

Battelle Marine Sciences Laboratory

Sequim, Washington

January 1997

Prepared for the

U.S. Army Corps of Engineers - New York District under a Related Services Agreement with the U.S. Department of Energy under Contract DE-AC06-76RLO 1830

Pacific Northwest National Laboratory Operated for the U.S. Department of Energy by Battelle Memorial Institute

\section{ติำ Battelle}




\title{
DISCLAIMER
}

This report was prepared as an account of work sponsored by an agency of the United States Government. Neither the United States Government nor any agency thereof, nor Battelle Memorial Institute, nor any of their employees, makes any warranty, express or implied, or assumes any legal liability or responsibility for the accuracy, completeness, or usefulness of any information, apparatus, product, or process disclosed, or represents that its use would not infringe privately owned rights. Reference herein to any specific commercial product, process, or service by trade name, trademark, manufacturer, or otherwise does not necessarily constitute or imply its endorsement, recommendation, or favoring by the United States Government or any agency thereof, or Battelle Memorial Institute. The views and opinions of authors expressed herein do not necessarily state or reflect those of the United States Government or any agency thereof.

\section{PACIFIC NORTHWEST NATIONAL LABORATORY operated by \\ BATTELLE MEMORIAL INSTITUTE for the \\ UNITED STATES DEPARTMENT OF ENERGY under Contract DE-AC06-76RLO 1830}

\author{
Printed in the United States of America
}

Available to DOE and DOE contractors from the Office of Scientific and Technical Information, P.O. Box 62, Oak Ridge, TN 37831; prices available from (615) 576-8401.

Available to the public from the National Technical Information Service, U.S. Department of Commerce, 5285 Port Royal Rd., Springfield, VA 22161 


\section{EVALUATION OF DREDGED MATERIAL PROPOSED FOR OCEAN DISPOSAL FROM HACKENSACK RIVER PROJECT AREA, NEW YORK}
B. D. Gruendell
E. S. Barrows
A. B. Borde

Battelle Marine Sciences Laboratory Sequim, Washington

January 1997

Prepared for the

U.S. Army Corps of Engineers - New York District under a Related Services Agreement with the U.S. Department of Energy under Contract DE-AC06-76RLO 1830

Pacific Northwest National Laboratory Richland, Washington 99352

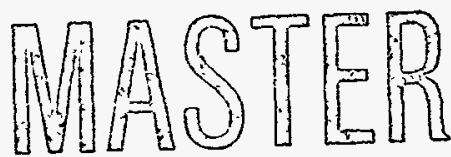





\section{DISCLAIMIER}

Portions of this document may be illegible in electronic image products. Images are produced from the best available original document. 


\section{Summary}

The objective of the bioassay reevaluation of the Hackensack River Federal Project was to reperform toxicity testing on proposed dredged material with current ammonia reduction protocols. Hackensack River was one of four waterways that the U.S. Army Corps of Engineers-New York District (USACE-NYD) requested the Battelle Marine Sciences Laboratory (MSL) to sample and to evaluate for dredging and disposal in April 1993. Sediment samples were re-collected from the Hackensack River Project area in August 1995.

Tests and analyses were conducted according to the manual developed by the USACE and the U.S. Environmental Protection Agency (EPA), Evaluation of Dredged Material Proposed for Ocean Disposal (Testing Manual), commonly referred to as the "Green Book," and the regional manual developed by the USACE-NYD and EPA Region II, Guidance for Performing Tests on Dredged Material to be Disposed of in Ocean Waters.

The reevaluation of proposed dredged material from the Hackensack River project area consisted of benthic acute toxicity tests. Thirty-three individual sediment core samples were collected from the Hackensack River project area. Three composite sediments, representing each reach of the area proposed for dredging, were used in benthic acute toxicity testing. Benthic acute toxicity tests were performed with the amphipod Ampelisca abdita and the mysid Mysidopsis bahia. The amphipod and mysid benthic toxicity test procedures followed EPA guidance for reduction of total ammonia concentrations in test systems prior to test initiation.

Statistically significant acute toxicity was found in all three Hackensack River composites in the static renewal tests with $A$. abdita, but not in the static tests with M. bahia. Statistically significant acute toxicity and a greater than $20 \%$ increase in mortality over the reference sediment was found in the static renewal tests with $A$. abdita. Statistically significant mortality $10 \%$ over reference sediment was observed in the $M$. bahia static tests. 


\section{Contents}

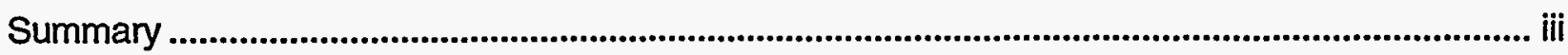

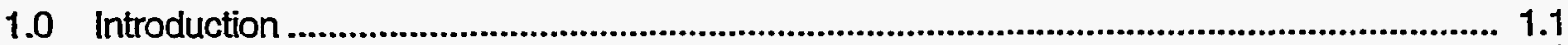

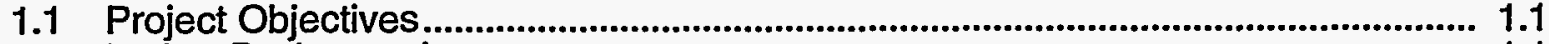

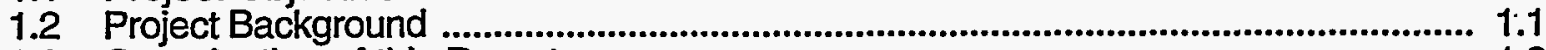

1.3 Organization of this Report ........................................................................................ 1.2

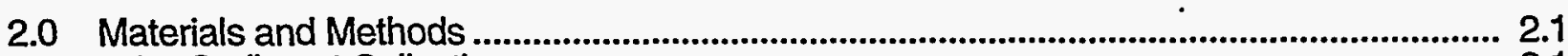

2.1 Sediment Collection ........................................................................................................... 2.1

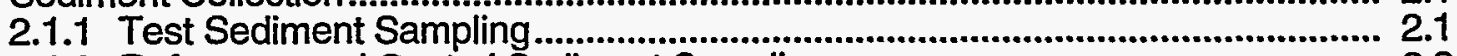

2.1.2 Reference and Control Sediment Sampling ................................................. 2.2

2.2 Test Organism Collection ............................................................................................... 2.3

2.3 Sediment Sample Preparation ......................................................................................... 2.3

2.3.1 Laboratory Preparation and Safety Considerations .......................................... 2... 2.4

2.3.2 Preparation of Sediment for Benthic Testing ....................................................... 2.5

2.4 Benthic Acute Toxicity Test Procedures ........................................................................ 2.5

2.4.1 Static Renewal Test with Ampelisca abdita ....................................................... 2.6

2.4.2 Static Test with Mysidopsis bahia .................................................................... 2.8

2.5 Data Analysis and Interpretation Procedures .......................................................... 2.10

2.5.1 Randomization .......................................................................................... 2.10

2.5.2 Statistical Analysis of Benthic Toxicity Tests ................................................ 2.. 2.10

2.6 Quality Assurance/Quality Control Procedures ....................................................... 2.10

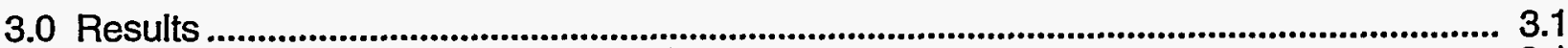

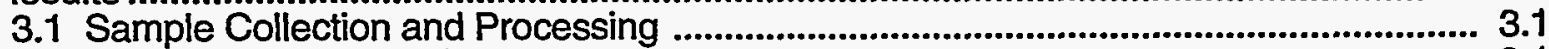

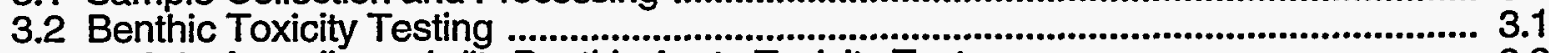

3.2.1 Ampelisca abdita Benthic Acute Toxicity Test ................................................ 3.2

3.2.2 Mysidopsis bahia Benthic Acute Toxicity Test................................................ 3.2

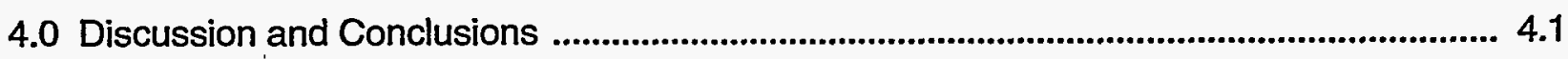

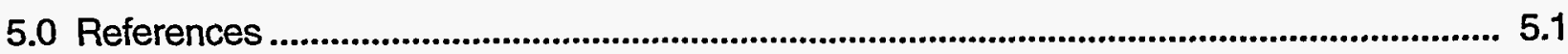

Appendix A. Benthic Acute Toxicity Test Data for Hackensack River Project ......................... A.1

\section{Figures}

FIGURE 1.1 Location of Hackensack River Project Area and Sample Collection Stations..... 1.3

FIGURE 2.1. Testing Containers for Benthic Static Renewal Toxicity Tests........................... 2.7

\section{Tables}

TABLE 3.1 Summary of Sediment Sample Data for Hackensack River Project Area ........... 3.2

TABLE 3.2 Summary of Benthic Tests Performed with Hackensack River Sediment Composites. 


\subsection{Introduction}

\subsection{Project Objectives}

The objective of the Hackensack River Project reevaluation was to retest proposed dredged material from the Hackensack River Project area, using current ammonia reduction protocols, to determine its acute toxicity compared with the sediment from the Mud Dump Site. Tests for Mud Dump disposal were conducted on Hackensack River sediment core samples according to the manual developed by the U.S. Army Corps of Engineers (USACE) and the U.S. Environmental Protection Agency (EPA), Evaluation of Dredged Material Proposed for Ocean Disposal (Testing Manual) (EPAJUSACE 1991), commonly referred to as the "Green Book," and the regional manual developed by the USACE-New York District (USACE-NYD) and EPA Region II, Guidance for Performing Tests on Dredged Material to be Disposed of in Ocean Waters (USACE-NYD/EPA Region II 1992), hereinafter referred to as the "Regional Guidance Manual." The Regional Guidance Manual provides specifications for the use of local or appropriate test species in biological tests and identifies chemical contaminants of concern.

Three composite sediments, representing each reach proposed for dredging, were used in benthic acute toxicity tests. Benthic acute toxicity tests were performed on the amphipod Ampelisca abdita and the mysid Mysidopsis bahia.

\subsection{Project Background}

The proposed Hackensack River project area was located along the western shore of Staten Island, New York (Figure 1.1). The project requires dredging and disposal of an estimated 300,000 cu yd of sediment. Project depth of the channel is $30 \mathrm{ft}$ plus $2 \mathrm{ft}$ overdepth ( $32 \mathrm{ft}$ ). Hackensack River was one of two waterways that the USACE-NYD requested the Battelle Marine Sciences Laboratory (MSL) to evaluate in a series of dredged material projects that became known as the New York/New Jersey Federal Projects 6 program. The projects evaluated under the Federal Projects 6 program were the Arthur Kill, New York/New Jersey and Hackensack River, New Jersey Federal Projects. Sediment samples from four reaches in these waterways were collected during a survey that took place from July 31 through August 4, 1995. Combining sample collection and evaluation of multiple dredged material projects was more cost-effective for the USACE-NYD, because the expense of sediment sampling, reference site testing, and quality control analyses could be shared among projects. 


\subsection{Organization of this Report}

Following this introduction, Section 2 presents the materials and methods used for sample collection, sample processing, toxicity testing, statistical data analysis, and quality assurance. Results of the bioassays are presented in Section 3. A discussion of the results and conclusions is provided in Section 4. Section 5 lists the literature cited in this report. Appendix A contains raw data associated with benthic acute toxicity tests: water quality measurements, test animal survival data, and reference toxicant test results. 


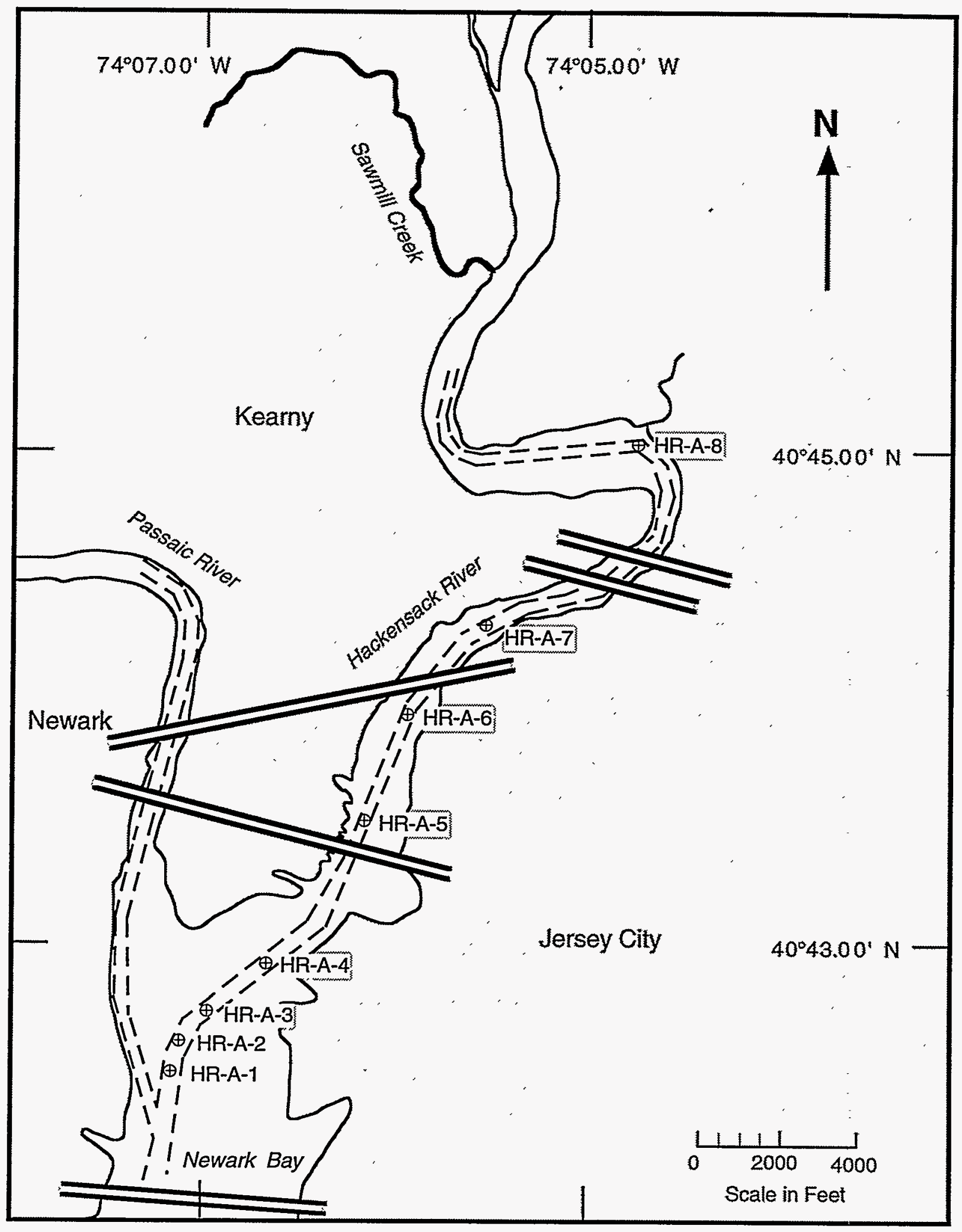

FIGURE 1.1. Location of Hackensack River Project Area and Sample Collection Stations 


\subsection{Materials and Methods}

\subsection{Sediment Collection}

Sediment samples were collected from eight stations within the Hackensack River project area. Sampling locations were selected by the USACE-NYD based on recent bathymetric surveys. The locations, their coordinates, and water and core sampling depths are presented with the sampling results in Section 3.0. Reference sediment was collected from the Mud Dump Reference Site aboard the MV Gelberman. All Hackensack River samples were collected aboard the M/N Hayward. Both vessels are owned and operated by USACE-NYD and located at Caven Point, New Jersey.

\subsubsection{Test Sediment Sampling}

The approximate core-sampling locations were first determined with the aid of reference to landmarks, such as shoreline features or buoys, as well as by water depth. Then, the vessel's onboard Differential Global Positioning System (dGPS) was used to identify and record (within $5 \mathrm{~m}$ ) each sampling station. The vessel's LORAN was available as a backup system. Water depth at the time of sampling was measured by lead line and confirmed with a fathometer on the boat. The actual water depth was converted to mean lower water (MLW) depth by correcting to the tide height at the time the depth was recorded. The difference between the MLW depth and the project depth, plus $2 \mathrm{ft}$ overdepth, yields the amount of core required.

Core samples were collected aboard the Hayward using an Ocean Surveys, Inc. vibracore sampler. The vibracore sampler consisted of a 4-in. outer diameter, steel core barrel attached to an pneumatic vibratory hammer. The vibratory hammer could be fitted to steel core barrels of various lengths, depending on the length of core needed. To collect a core sample, the core barrel was fitted with a 3.125-in. interior diameter, steam-cleaned, Lexan polycarbonate tube. The vibracore was then suspended by the ship's crane. Once the coring apparatus was directly above the sampling station, the core was lowered through the water to the sediment surface. At this point, the station coordinates were recorded from the vessel's dGPS, and water depth was recorded by lead line. The vibratory hammer was switched on until the corer penetrated through the sediment to the desired project depth. Adequate penetration was determined relative to marks on the outside of the core barrel and on the cable suspending the vibracore from the crane. The vibracore apparatus was then pulled out of the sediment and lowered onto the ship's deck. A cutter-head and core-catcher assembly prevented loss of the sediment through the bottom of the 
core liner. After each core was brought on board, the liner was pulled from the barrel and the length of cored sediment was measured from the mudline to determine whether the project depth plus $2 \mathrm{ft}$ overdepth had been reached. If the sediment core length was at least project depth plus $2 \mathrm{ft}$ overdepth, it was capped, sealed with tape, and labeled. If the sediment core length was not to project depth the sediment sample was discarded and another sample was taken at the same location (within $\sim 20 \mathrm{ft}$ ), until project depth was reached or it was determined that the substrate prevented further penetration of the coring device. While on board the sampling vessel, cores were kept cool $\left(\sim 4^{\circ} \mathrm{C}\right)$ in a freezer on the deck of the boat. If necessary, cores were cut into shorter sections to fit in the freezer.

A log book was maintained containing records of each sample collected, consisting of station designation, coordinates, replicate number, date, sampling time, water depth, core length, and number of sections per core. At the end of each sampling day, when the Hayward returned to Caven Point, all sediment cores were loaded into a locked refrigerated van, thermostatically controlled to maintain temperature at $\sim 4^{\circ} \mathrm{C}$. Sample identification numbers were logged on chainof-custody forms daily.

At the conclusion of the sample collection survey, sediment cores were shipped by refrigerated van from Caven Point, New Jersey, to the MSL in Sequim, Washington. The shipment departed from Caven Point on August 4, 1995, and arrived at the MSL on August 9 , 1995.

\subsubsection{Reference and Control Sediment Sampling}

Reference sediments for acute toxicity tests were collected from the Mud Dump Reference Site. Three, 5-gal containers of surficial sediment were collected the reference site using a van Veen grab sampler. After recovery, water was drained from the sampler, and the sediments were transferred to epoxy-coated steel buckets. The buckets were covered, labeled, and kept cool $\left(\sim 4^{\circ} \mathrm{C}\right)$ in a freezer on deck while aboard the boat. Records for collected reference sediment included coordinates, replicate number, date, sampling time, and water depth. Reference sediment samples were loaded into the refrigerated van at the staging area upon return to port, and sample identification numbers were logged on chain-of-custody forms.

Control sediments were used in each toxicity and bioaccumulation test to validate test procedures. Control sediment used in M. bahia tests was collected from Sequim Bay, Washington, using a van Veen grab sampler deployed from an MSL research vessel. Native control sediment for $A$. abdita was supplied with the test organisms by the respective supplier. 


\subsection{Test Organism Collection}

Two species of test organisms were used to evaluate sediment samples from the Hackensack River project area:

- $\quad$ Ampelisca abdita, a tube-dwelling, surface detrital-feeding amphipod

- $\quad$ Mysidopsis bahia, a juvenile mysid shrimp.

Ampelisca abdita except mysids were wild-captured, collected by the commercial supplier, East Coast Amphipod, Kingston, Rhode Island. A. abdita and its native sediment were collected from Narragansett Bay, Rhode Island, by dragging a large dipnet along the sediment surface. Test organisms were carefully removed from their tubes for counting, and then placed in clean, native sediment for overnight transport to the MSL. Mysidopsis bahia were purchased from Aquatic Biosystems, Fort Collins, Colorado. Mysids that were less than 24-h old were shipped via overnight delivery in plastic bags containing oxygen-supersaturated seawater maintained at approximately $15^{\circ} \mathrm{C}$ with "blue ice."

All organisms were shipped or transported either in native sediment or under other conditions designed to ensure their viability. After their arrival at the MSL, the test organisms were gradually acclimated to test conditions. Animals with abnormal behavior or appearance were not used in toxicological tests. All acclimation and animal care records are part of the raw data files for these projects.

\subsection{Sediment Sample Preparation}

Sediment sample preparation consists of all steps performed in the laboratory between receipt of the samples at the MSL and the preparation of samples for biological testing. Sediment samples for archiving and biological analysis were prepared from individual core samples, composites of a number of core samples, reference sediment, and control sediment. All sediment samples were assigned random, unique code numbers to ensure that samples were handled without bias by staff in the biology laboratory.

Sediment for biological testing was used within the 6-week holding period specified in the Green Book. During this holding time, the sediment samples were received at the MSL; inventoried against chain-of-custody forms; processed and used for benthic toxicity tests, and subsampled for archiving. This section describes procedures followed for equipment preparation, compositing strategy, and preparation of sediments for biological testing and archiving. 


\subsubsection{Laboratory Preparation and Safety Considerations}

All glassware, stainless-steel or titanium utensils, Nalgene, Teflon, and other laboratory containers and equipment underwent stringent cleaning procedures to avoid contamination of samples. Glassware (e.g., test containers, aquaria, sediment transfer dishes) was washed with hot water and detergent, rinsed with deionized water, then soaked in a $10 \%$ solution of reagent grade nitric acid for a minimum of $4 \mathrm{~h}$ and rinsed again with deionized water before it was allowed to air dry. Polyvinyl chloride (PVC), Nalgene, and Teflon tools were then rinsed with methylene chloride and allowed to dry under a fume hood. Stainless-steel bowls, spoons, spatulas, and other utensils were washed with hot water and detergent, rinsed with deionized water, and allowed to air dry. They were then solvent-rinsed with methylene chloride and allowed to dry under a fume hood.

Neoprene stoppers and polyethylene sheets or other porous materials were washed with hot water and detergent and rinsed with deionized water. These items were then "seasoned" by continuous soaking in $0.45-\mu \mathrm{m}$ filtered seawater for at least 2 days prior to use. Large pieces of laboratory equipment, such as the epoxy-coated sediment mixer, were washed with a dilute solution of detergent, and thoroughly rinsed with tap water followed by deionized water or filtered seawater.

Equipment used for determining water quality, including the meters for $\mathrm{pH}$, dissolved oxygen (DO), temperature, ammonia and salinity, were calibrated according to the manufacturers' specifications and internal MSL standard operating procedures (SOPs).

Because the potential toxicity of the Hackensack River sediment was unknown, sediment processing and testing were segregated from other laboratory activities. Specific areas at the MSL were established for sample storage and for core-cutting, sediment mixing, and sediment sieving. Work areas were covered with plastic sheeting to contain any waste sediment. Wastewater generated during all operations was retained in 55-gal barrels and periodically pumped through activated charcoal filters and into the MSL's wastewater treatment system. These procedures minimized any potential for cross-contamination of sediment samples and any potential accidental release to the environment.

Laboratory staff members were protected by personal safety equipment such as eyewear, Tyvek suits, plastic aprons, and rubber gloves. Those who were likely to have the most exposure to the potential volatile compounds in the bulk sediment (i.e., those responsible for opening, homogenizing, and compositing core samples) were also provided with half-mask respirators. 


\subsubsection{Preparation of Sediment for Benthic Testing}

Each Lexan core liner was opened by scoring the core longitudinally with a circular saw, then finishing the cut and opening the core with a clean, solvent-rinsed linoleum knife to expose the sediment. As each sediment core sample was opened, it was examined for physical characteristics (e.g., sediment type and consistency, color, odor). In particular, the presence of any strata in the cores was noted. All core observations were recorded in the sediment preparation log book. The sediment between the mudline and project depth was then transferred from the core liner to a clean, stainless-steel bowl by scooping the sediment from the core liner with a spoon or spatula. The sediment was mixed by hand with stainless-steel utensils until the color and consistency appeared homogenous, creating a sample representative of the individual sampling station. Sieving was not necessary because organisms that may interfere with test results were not observed in the sediment samples.

Aliquots of the homogenized sediment were then transferred to the appropriate sample jar(s) for an archive sample. The remainder of the sediment from the individual core stations was combined in an epoxy-coated cement mixer to create one composite sample representing the Hackensack River project area, designated COMP HR. The HR composite contained sediments from stations HR-1 through HR-8. The composited reach sediment was used for solid-phase toxicity as required by USACE-NYD. Aliquots of homogenized composite sediment were transferred to the archive sample jar(s). The remainder was stored in labeled epoxy-coated pails, tightly covered, at $4^{\circ} \mathrm{C} \pm 2^{\circ} \mathrm{C}$ until use for benthic toxicity.

The Mud Dump Reference Site sediment, $A$. abdita, and M. bahia native control sediment were also homogenized in the large, stainless-steel bowls, and prior to mixing, reference sediment was pressed through a 1-mm mesh sieve to remove live organisms that might affect the outcome of toxicity tests. After mixing, aliquots for archiving were removed. Native control sediment for A. abdita and $M$. bahia was passed through a $0.5-\mathrm{mm}$ mesh sieve to remove live organisms and mixed in stainless-steel bowls after sieving. All reference and control sediments were stored at $4^{\circ} \mathrm{C} \pm 2^{\circ} \mathrm{C}$ until used in benthic toxicity tests.

\subsection{Benthic Acute Toxicity Test Procedures}

Deposited sediment effects of open-water dredged material disposal were evaluated by benthic acute toxicity tests with the marine amphipod $A$. abdita and the mysid M. bahia. 


\subsubsection{Static Renewal Test with Ampelisca abdita}

Upon receipt, $A$. abdita were placed in a tub of clean sediment from their collection area and gradually acclimated to laboratory conditions with unfiltered flowing Sequim Bay seawater. A. abdita were received at approximately $12^{\circ} \mathrm{C}$ and acclimated to $20^{\circ} \mathrm{C} \pm 2^{\circ} \mathrm{C}$ over 5 days. The A. abdita were not fed prior to testing.

All amphipod static renewal tests were performed in $1 \mathrm{~L}$ glass jars modified for use as flow-through test chambers. The test chambers were fitted with funneled lids and screened overflow ports (Figure 2.1). To prepare each test container, $200 \mathrm{~mL}$ of clean seawater was placed in each jar. Sediment was added until water was displaced to a volume of $400 \mathrm{~mL}$, then seawater was added to a total volume of $750 \mathrm{~mL}$. Five replicates of each Hackensack River composite sediment, Mud Dump Reference Site sediment, and native test animal control treatments were tested.

Concentrations of ammonia have been encountered in the pore water of sediment core samples from New York/New Jersey waterways at levels high enough to affect survival of amphipods in benthic toxicity tests (Barrows et al. 1996). Therefore, the amphipod tests were conducted according to the ammonia protocols issued by EPA and USACE (EPAUSACE 1993). This guidance requires postponing test initiation (exposure of test animals) until pore water total ammonia concentrations are reduced to $<20 \mathrm{mg} / \mathrm{L}$ by overlying water replacement for $A$. abdita. During this "purging" period, test chambers were maintained under test conditions, and the flowthrough system was turned on periodically, to deliver the seawater at a rate of two exchanges per day. Pore water ammonia measurements were made on "dummy" containers that were set up and maintained in the same manner as the actual test containers but without animals added to them. The pore water was obtained by siphoning off the overlying water in the dummy jar and centrifuging the sediment in a Teflon jar for at least $20 \mathrm{~min}$ at approximately $3000 \mathrm{rpm}$. Salinity, temperature, and $\mathrm{pH}$ were also determined in the pore water samples. Once the test was initiated, overlying water was renewed at a rate of two chamber exchanges per day throughout the 10-day tests.

The amphipod benthic toxicity tests were initiated by the addition of 20 organisms to each test chamber for a test population of 100 amphipods per sediment treatment. Amphipods were gently sieved from their native sediment in holding tanks and transferred to shallow baking dishes. For each test chamber, five animals were counted and transferred by pipet into each of four small, plastic cups containing a small amount of filtered seawater. The animals in each transfer cup were recounted by a second analyst. The animals were placed in the test chamber by pouring the contents of each of four cups into the test chamber. 


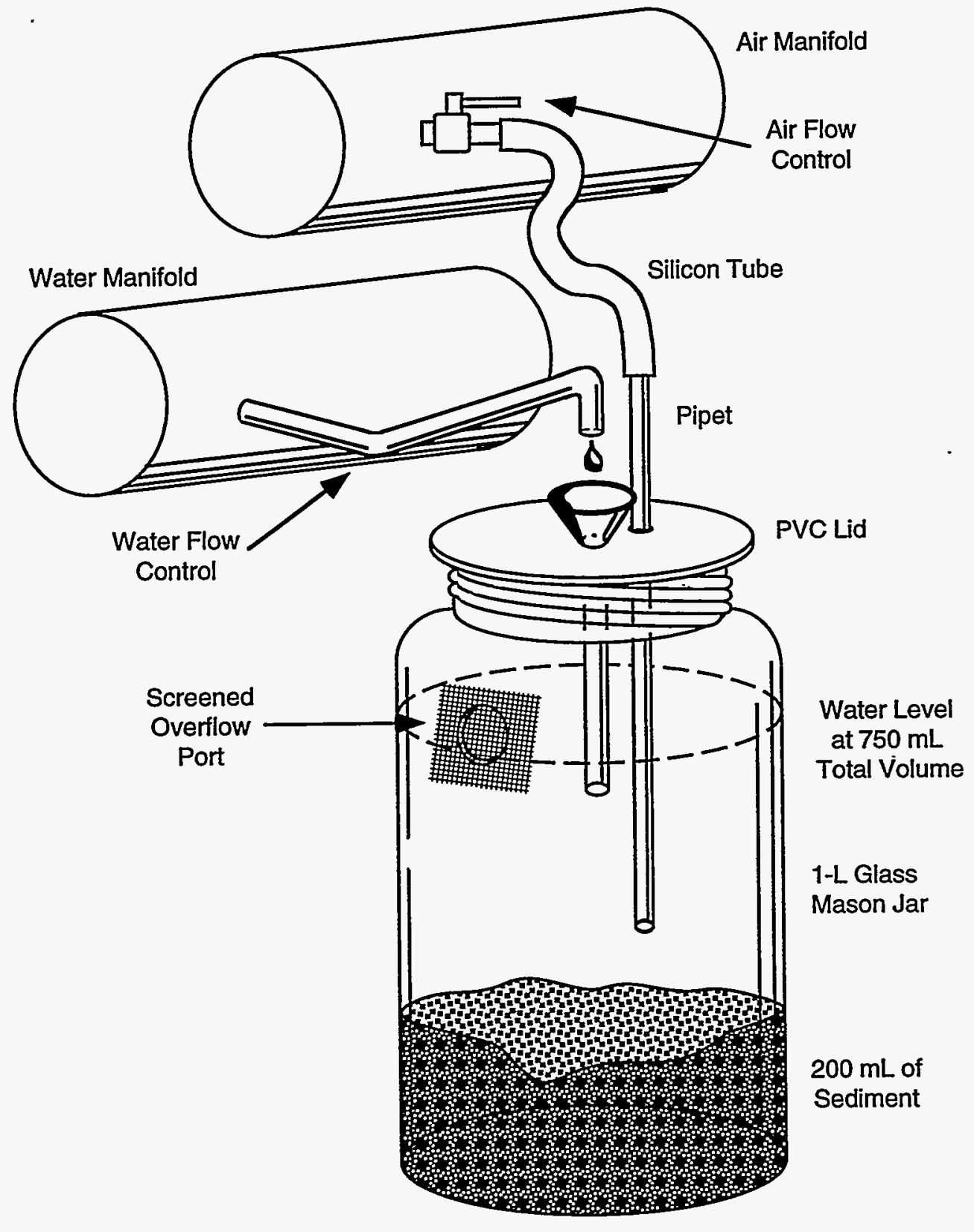

FIGURE 2.1. Testing Containers for Static Renewal Benthic Toxicity Tests 
Salinity, temperature, $\mathrm{DO}$, and $\mathrm{pH}$ were measured in overlying water in all replicates prior to test initiation, in at least one replicate per treatment daily, and in all replicates at test termination. Measurements of total ammonia levels in the overlying water and porewater also continued during testing. Overlying water ammonia was measured in all replicates prior to test initiation (Day 0 ), in at least one replicate per treatment daily, and in all replicates at test termination (Day 10). Pore water ammonia was measured on Day 0 and Day 10 in the "dummy" containers. The following were the acceptable ranges for water quality parameters during the amphipod tests:

$\begin{array}{ll}\text { Temperature } & 20^{\circ} \mathrm{C} \pm 2^{\circ} \mathrm{C} \\ \mathrm{DO} & >60 \% \text { saturation } \\ \text { pH } & 7.8 \pm 0.5 \\ \text { Salinity } & 30 \% \pm 2 \% \circ \\ \text { Ammonia } & 20 \mathrm{mg} / \mathrm{L} \text { in porewater } \\ \text { Renewal Rate } & 2 \text { volume exchanges/day. }\end{array}$

Gentle aeration was provided throughout the test, and the amphipods were not fed during testing. At the end of the 10-day period, the contents of each chamber were gently sieved through 0.5-mm mesh, and the number of live, dead, and missing amphipods was recorded on termination forms. An animal was considered dead if it did not respond to gentle probing. As a quality control check, a second observer confirmed surviving test organisms on at least $10 \%$ of the termination counts.

Reference toxicant tests with cadmium chloride were performed concurrently with the A. abdita solid-phase exposure. The reference toxicant tests were $96-\mathrm{h}$, water-only exposures that were otherwise conducted following the same procedures as for the static tests with sediment. A. abdita were exposed to nominal concentrations of $0,0.19,0.380 .75$, and $1.5 \mathrm{mg} / \mathrm{L}$ Cd.

\subsubsection{Static Test with Mysidopsis bahia}

Upon receipt at the laboratory, $M$. bahia were placed in 10-gal aquaria and gradually acclimated from $25 \%$ seawater to $30 \%$ with Sequim Bay seawater over a 3-day period. $M$. bahia were received and held for 3 days at $20^{\circ} \mathrm{C} \pm 2^{\circ} \mathrm{C}$ until testing and were fed concentrated brine shrimp nauplii twice daily prior to testing. Mortality of $M$. bahia during holding was less than $1 \%$.

The 10-day static benthic acute toxicity test with $M$. bahia was performed in $1 \mathrm{~L}$ glass jars modified for use as flow-through test chambers. The test chambers were fitted with funneled lids and screened overflow ports (Figure 2.1). To prepare each test container, $200 \mathrm{~mL}$ of clean seawater was placed in each jar. Sediment was added until water was displaced to a volume of $400 \mathrm{~mL}$, then seawater was added to the total volume of $750 \mathrm{~mL}$. Five replicates of each Hackensack River sediment composite, and Mud Dump Reference Site sediment were tested. 
Concentrations of ammonia have been encountered in the pore water of sediment core samples from New York/New Jersey waterways at levels high enough at levels high enough to affect overlying water ammonia levels and survival of mysids in benthic toxicity tests (Barrows et al. 1996). Therefore, the mysid tests were conducted according to the ammonia protocols issued by EPA and USACE (EPA/USACE 1993). This guidance requires postponing test initiation (exposure of test animals) until overlying water total ammonia concentrations are reduced to $<20$ $\mathrm{mg} / \mathrm{L}$ by overlying water replacement for $M$. bahia. During this "purging" period, test chambers were maintained under test conditions, and the flow-through system was turned on periodically, to deliver the seawater at a rate of two exchanges per day. Overlying water ammonia measurements were made on test containers. Salinity, temperature, and $\mathrm{pH}$ were also determined in the overlying water samples. Once the test was initiated, overlying water was not renewed and the 10-day test was conducted in static conditions.

The $M$. bahia benthic toxicity test was initiated by the addition of 20 organisms to each test chamber for a test population of 100 mysids per sediment treatment. M. bahia were transferred from holding tanks to shallow glass dishes. For each test chamber, five animals were counted and transferred by pipet into each of four small, plastic cups. The animals in each transfer cup were recounted by a second analyst. The animals were placed in the test chamber by dipping the cup below the surface of the water to release the animals.

Salinity, temperature, $\mathrm{DO}, \mathrm{pH}$, and total ammonia in overlying water were measured in all replicates prior to test initiation, in at least one replicate per treatment daily, and in all replicates at test termination. The following were the acceptable ranges for water quality parameters during the mysid benthic test:

$$
\begin{array}{ll}
\text { Temperature } & 20^{\circ} \mathrm{C} \pm 2^{\circ} \mathrm{C} \\
\mathrm{DO} & >40 \% \text { saturation } \\
\text { pH } & 7.8 \pm 0.5 \\
\text { Salinity } & 30 \%+2 \% \circ . \\
\text { Ammonia } \quad . . & 20 \mathrm{mg} / \mathrm{L} \text { in overlying water. }
\end{array}
$$

Gentle aeration was provided to all test chambers during the test to maintain consistency in DO concentration among test chambers. At the end of the 10-day period, the contents of each chamber were gently sieved through $0.5-\mathrm{mm}$ mesh, and the number of live and dead or missing M. bahia was recorded on termination forms. An animal was considered dead if it did not respond to gentle prodding. As a quality control check, a second observer confirmed surviving test organisms on at least $10 \%$ of the termination counts.

Reference toxicant tests with copper were performed concurrently with the M. bahia solidphase exposure. The reference toxicant tests were $96-h$, water-only exposures that were otherwise conducted following the same procedures as for the static tests with sediment. M. bahia were exposed to nominal concentrations of $0,0.15,0.2,0.3$, and $0.4 \mathrm{mg} / \mathrm{L} \mathrm{Cu}$. 


\subsection{Data Analysis and Interpretation Procedures}

Statistical analyses were conducted to determine the magnitude and significance of toxicity and bioaccumulation in test treatments relative to the reference treatment. Each statistical test was based on a completely random design that allowed unbiased comparison among treatments.

\subsubsection{Randomization}

All water-column and benthic toxicity tests were designed as completely random tests. Organisms were randomly allocated to treatments, and treatments were randomly positioned on

water tables. To determine randomization, a random-number table was generated for each test using the discrete random-number generator in Microsoft's Excel spreadsheet software.

\subsubsection{Statistical Analysis of Benthic Toxicity Tests}

Benthic toxicity of all sediment treatments was compared with a single reference treatment using Dunnett's test (Dunnett 1964). The arcsine square root of the proportion of organisms surviving the test was used to stabilize the within-class variances. As recommended by the Green Book, an experiment-wise error $\alpha=0.05$. was used.

\subsection{Quality Assurance/Quality Control Procedures}

The quality assurance/quality control (QA/QC) procedures for the Hackensack River Project were consistent with the Regional Guidance Manual and the Green Book, and were documented in the Work/Quality Assurance Project Plan, Evaluation of Dredged Material Proposed for Ocean Disposal from Federal Projects in New York (Part 2), prepared by the MSL and submitted to the USACE-NYD for this program. This document describes all QA/QC procedures that were followed for sample collection, sample tracking and storage, and physical/chemical analyses. A member of Pacific Northwest National Laboratory's quality engineering staff was present throughout all phases of this program to observe procedures, review and audit data, and ensure that accepted protocols were followed. Laboratory notebooks or data accumulation notebooks were assigned to each portion of these studies and served as records of day-to-day project activities. 


\subsection{Results}

This section presents results of sample collection and processing, and physical and chemical analyses conducted on sediment samples collected from the proposed Hackensack River dredging area.

\subsection{Sample Collection and Processing}

Sediment core samples were collected from the Hackensack River project area on August 2, 1995 (Figure 1.1). Table 3.1 lists each sampling station within the Hackensack River project area, sampling coordinates, collection date, length of core required for testing (including $2 \mathrm{ft}$ of overdepth), and length of core actually collected. All samples were collected aboard the Hayward. Eight core samples were collected from the Hackensack River channel and all were collected to project depth (-30 ft MLW) plus $2 \mathrm{ft}$ of overdepth, except for HR-7 which was collected to project depth but was $0.7 \mathrm{ft}$ short of overdepth.

Upon delivery of the sediment core samples to the MSL on August 9, 1995, samples were composited according to the procedures described in Section 2. Individual sediment core samples were subsampled for archiving and then combined with other core samples to create one composited sediment. One composited sediment sample representing the Hackensack River project area (COMP HR) was used in benthic testing and subsampled for archiving. COMP HR consisted of stations HR-1 through HR-8.

\subsection{Benthic Toxicity Testing}

Benthic tests were performed on the Hackensack River sediment composite. Benthic acute toxicity tests were performed with the infaunal amphipod $A$. abdita and the mysid M. bahia. This section discusses the results of all sediment and reference toxicant testing. Complete test results, water quality measurements, and the results of the reference toxicant tests are presented in Appendix A. Throughout this section, the term "significant difference" is used to express statistically significant differences at $\alpha=0.05$ only. Tests for statistical significance between test treatments and control or reference treatments were performed following methods outlined in Section 2.6. 
TABLE 3.1. Summary of Sediment Sample Data for Hackensack River Project Area

\begin{tabular}{|c|c|c|c|c|c|c|}
\hline \multirow[b]{2}{*}{ Station } & \multirow{2}{*}{$\begin{array}{c}\text { Collection } \\
\text { Date } \\
\end{array}$} & \multicolumn{2}{|c|}{ dGPS Station Coordinates } & \multirow{2}{*}{$\begin{array}{l}\text { Core Length } \\
\text { Required (ft) }\end{array}$} & \multirow{2}{*}{$\begin{array}{l}\text { Core Length } \\
\text { Collected (ft) }\end{array}$} & \multirow{2}{*}{$\begin{array}{l}\text { Depth } \\
\text { (fi) }\end{array}$} \\
\hline & & Latitude $N$ & Longitude W & & & \\
\hline HR-1 & $8 / 02 / 95$ & $40^{\circ} 42.48^{\prime}$ & $74^{\circ} 07.07^{\prime}$ & 4.5 & 4.5 & 27.5 \\
\hline HR-2 & $8 / 02 / 95$ & $40^{\circ} 42.58^{\prime}$ & $74^{\circ} 06.95^{\prime}$ & 6.5 & 6.5 & 25.5 \\
\hline HR-3 & $8 / 02 / 95$ & $40^{\circ} 42.68^{\prime}$ & $74^{\circ} 06.85^{\prime}$ & 7.2 & 7.0 & 24.8 \\
\hline HR-4 & $8 / 02 / 95$ & $40^{\circ} 42.78^{\prime}$ & $74^{\circ} 06.65^{\prime}$ & 4.6 & .5 .0 & 27.4 \\
\hline HR-5 & $8 / 02 / 95$ & $40^{\circ} 43.20^{\prime}$ & $74^{\circ} 06.22 '$ & 4.6 & 5.0 & 27.4 \\
\hline HR-6 & $8 / 02 / 95$ & $40^{\circ} 43.87^{\prime}$ & $74^{\circ} 05.82^{\prime}$ & 3.0 & 3.0 & 29.0 \\
\hline HR-7 & $8 / 02 / 95$ & $40^{\circ} 44.28^{\prime}$ & $74^{\circ} 05.42^{\prime}$ & 4.7 & 4.0 & 27.3 \\
\hline HR-8 & $8 / 02 / 95$ & $40^{\circ} 44.95^{\prime}(a)$ & $74^{\circ} 04.75^{\prime}(a)$ & 7.5 & 8.0 & 24.5 \\
\hline \multicolumn{7}{|c|}{ Grab Samples } \\
\hline MDRSI & $8 / 02 / 95$ & $40^{\circ} 20.22^{\prime}$ & $73^{\circ} 52.18^{\prime}$ & $\ldots-(c)$ & - & $N D$ (d) \\
\hline
\end{tabular}

(a) Differential correction not receivable, position by GPS without correction.

(b) MDRS Mud Dump Reference Site.

(c) - Not applicable.

(d) ND No data collected.

\subsubsection{Ampelisca abdita Benthic Acute Toxicity Test}

Results of the benthic acute toxicity test with $A$. abdita are summarized in Table 3.2. Complete test results and water quality data are presented in Appendix A, Tables A.1 through A.4. Survival in the A. abdita control sediment was $95 \%$. Amphipod survival was $67 \%$ for the HR composite, and $93 \%$ in the Mud Dump reference. A. abdita survival in the HR composite was significantly different than in the Mud Dump reference, and $20 \%$ different.

Water quality parameters were within acceptable ranges throughout the test. Prior to ammonia reduction procedures, the porewater ammonia concentration in COMP HR was 110 $\mathrm{mg} / \mathrm{L}$. Overlying water in test containers was renewed twice daily for 12 days until porewater ammonia was $11.9 \mathrm{mg} / \mathrm{L}$. Renewal of overlying water was continued twice daily during the 10day test. Concentrations of ammonia in overlying water did not exceed $1.4 \mathrm{mg} / \mathrm{L}$ during the test. The Cd reference toxicant test produced an $\mathrm{LC}_{50}$ of $0.61 \mathrm{mg} / \mathrm{L} \mathrm{Cd}$, within the control range established at the MSL $(0.5 \mathrm{mg} / \mathrm{L}$ to $1.4 \mathrm{mg} / \mathrm{L} \mathrm{Cd})$.

\subsubsection{Mysidopsis bahia Benthic-Static Acute Toxicity Test}

Results of the benthic-static acute toxicity test with $M$. bahia are summarized in Table 3.2. Complete test results and water quality data are presented in Appendix A, Tables A.1 through A.7. Survival was $93 \%$ in COMP HR and $91 \%$ in the Mud Dump Reference Site. The control 
TABLE 3.2. Summary of Benthic Tests Performed with Hackensack River Sediment Composites

\begin{tabular}{|c|c|c|c|c|}
\hline $\begin{array}{l}\text { Test Organism } \\
\text { and Composite }\end{array}$ & $\begin{array}{l}\text { Mean \% } \\
\text { Survival }\end{array}$ & $\begin{array}{c}\text { Significantly } \\
\text { Different Than } \\
\text { MDRS(a) }\end{array}$ & $\begin{array}{c}20 \% \\
\text { Difference } \\
\text { from MDRS } \\
\end{array}$ & $\begin{array}{c}10 \% \\
\text { Difference } \\
\text { from MDRS }\end{array}$ \\
\hline $\begin{array}{l}\text { A. abdita (HR) } \\
\text { A. abdita (MDRS) } \\
\text { A. abdita (Control) }\end{array}$ & $\begin{array}{l}67 \% \\
93 \% \\
95 \%\end{array}$ & $\begin{array}{l}\text { Yes } \\
-- \\
--\end{array}$ & $\begin{array}{l}\text { Yes } \\
--\end{array}$ & $\begin{array}{l}--(b) \\
-- \\
--\end{array}$ \\
\hline $\begin{array}{l}\text { M. bahia (HR) } \\
\text { M. bahia (MDRS) } \\
\text { M. bahia (Control) }\end{array}$ & $\begin{array}{l}93 \% \\
91 \% \\
95 \%\end{array}$ & $\begin{array}{l}\text { No } \\
-- \\
--\end{array}$ & $\begin{array}{l}-- \\
--\end{array}$ & $\begin{array}{l}\text { No } \\
--\end{array}$ \\
\hline
\end{tabular}

(a) MDRS Mud Dump Reference Site.

(b) -- Not Applicable.

sediment survival was $95 \%$, validating the test. $M$. bahia survival in the HR composite was not significantly different than in the Mud Dump reference.

All water quality parameters were within acceptable ranges throughout the test, except for minor deviations in. $\mathrm{pH}$ measurements rising to 8.45 units in the control. Prior to ammonia reduction procedures, the porewater ammonia concentration in COMP HR was $110 \mathrm{mg} / \mathrm{L}$. Overlying water in test containers was renewed once; overlying water ammonia was $8.0 \mathrm{mg} / \mathrm{L}$, porewater ammonia was $40.3 \mathrm{mg} / \mathrm{L}$. Renewal of overlying water was discontinued once the test was initiated, and the test was run static. Concentrations of ammonia in the overlying water ranged from $<1.0 \mathrm{mg} / \mathrm{L}$ to $8.0 \mathrm{mg} / \mathrm{L}$ during the test. The Cu reference toxicant test produced an $\mathrm{LC}_{50}$ of $195 \mu \mathrm{g} / \mathrm{L} \mathrm{Cu}$, which was within the control range established at the MSL (116 $\mu \mathrm{g} / \mathrm{L}$ to $229 \mu \mathrm{g} / \mathrm{L}$ $\mathrm{Cu})$. 


\subsection{Discussion and Conclusions}

In this section, physical and chemical analyses, and bioassays performed on the Hackensack River sediment composite are evaluated relative to the Mud Dump Reference Site sediment by the guidelines of the Green Book Tier III. Tier III evaluations include water-column toxicity tests, benthic toxicity tests, and whole-sediment bioaccumulation studies. Tier III evaluations assess the impact of contaminants in the dredged material on marine organisms to determine whether there is potential for the material to have an unacceptable environmental effect during ocean disposal.

The Green Book provides the following guidance for determining whether the proposed dredged material is unacceptable for ocean disposal based on the Tier III benthic acute toxicity test:

The proposed dredged material does not meet the limiting permissible concentration (LPC) for benthic toxicity when organism survival in the test sediment and the reference site sediment is statistically significantly different, and the decrease in survival exceeds $20 \%$ for $A$. abdita, or $10 \%$ for $M$. bahia.

In comparison with the Mud Dump Reference Site, statistically significant acute toxicity and greater than $20 \%$ increase in mortality was found in the Hackensack River composite in the static renewal test with $A$. abdita. In comparison with the Mud Dump Reference Site, no statistically significant acute toxicity nor greater than $10 \%$ increase in mortality was found with the Hackensack River composite in the static test with $M$. bahia. The increase in $A$. abdita mortality was not related to ammonia concentrations. The Hackensack River sediment composite did not meet the LPC for benthic toxicity to the test organism $A$. abdita, but the LPC was met for the test organism M. bahia. 


\subsection{References}

Barrows, E.S., M.R. Pinza, W.W. Gardiner, N.P. Kohn, B.D. Gruendell, H.L. Mayhew, J.Q.

Word, and L.B. Rosman. 1996. Evaluation of Dredged Material Proposed for Ocean Disposal from Federal Projects in New York and New Jersey and the Military Ocean Terminal (MOTBY). Prepared for Department of the Army, U.S. Army Corps of Engineers, New York District, Water Quality Branch by Battelle Marine Sciences Laboratory, Pacific Northwest Natianal Laboratory, Richland Washington.

Dunnett, C.W. 1964. "New Tables for Multiple Comparisons with a Control." Biometrics 20:482-491.

EPA/USACE (U.S. Environmental Protection Agency/U.S. Army Corps of Engineers). 1991. Evaluation of Dredged Material Proposed for Ocean Disposal (Testing Manual). EPA-503/891/001. U.S. Environmental Protection Agency, Office of Marine and Estuarine Protection, Washington, D.C.

EPAJUSACE (U.S. Environmental Protection Agency/U.S. Army Corps of Engineers). 1993. Memorandum: Technical Panel Recommendations Concerning Use of Acute Amphipod Tests in Evaluation of Dredged Material. December 21, 1993. U.S. Environmental Protection Agency/U.S. Army Corps of Engineers, Washington, D.C.

USACE-NYD/EPA Region II (U.S. Army Corps of Engineers, New York District/U.S.

Environmental Protection Agency, Region II). 1992. Guidance for Performing Tests on Dredged Material Proposed for Ocean Disposal. 18 December 1992 Draft. U.S. Army Corps of Engineers, New York District and U.S. Environmental Protection Agency, Region II. New York, New York. 
Appendix A.

Benthic Acute Toxicity Test Data for Hackensack River Project 
Table A.1. Results for 10-Day, Static Renewal, Benthic Acute Toxicity Test with $A$. abdita, Hackensack River

\begin{tabular}{|c|c|c|c|c|c|c|}
\hline $\begin{array}{l}\text { Sediment } \\
\text { Treatment }\end{array}$ & Replicate & Live $^{(a)}$ & $\begin{array}{l}\text { Dead or } \\
\text { Missing }\end{array}$ & $\begin{array}{l}\text { Proportion } \\
\text { Surviving }\end{array}$ & $\begin{array}{c}\text { Mean } \\
\text { Proportion } \\
\text { Surviving }\end{array}$ & $\begin{array}{l}\text { Standard } \\
\text { Deviation }\end{array}$ \\
\hline COMP HR & 1 & 11 & 9 & 0,55 & - & \\
\hline COMP HR & 2 & 14 & 6 & $0 ; 70$ & & \\
\hline COMP HR & 3 & 16 & 4 & 0.80 & 0.67 & 0.10 \\
\hline COMP HR & 4 & 14 & 6 & 0.70 & & \\
\hline COMP HR & 5 & 12 & 8 & 0.60 & & \\
\hline \multicolumn{7}{|l|}{ Reference } \\
\hline $\mathrm{MDRS}^{(\mathrm{m})}$ & 1 & 17 & 3 & 0.85 & & \\
\hline MDRS & 2 & 20 & 0 & 1.00 & & \\
\hline MDRS & 3 & 18 & 2 & 0.90 & 0.93 & 0.07 \\
\hline MDRS & 4 & 18 & 12 & 0.90 & & \\
\hline MDRS & 5 & 20 & 0 & 1.00 & & \\
\hline Ampelisca Control & 1 & 18 & 2 & 0.90 & & \\
\hline Ampelisca Control & 2 & 19 & 1 & 0.95 & & \\
\hline Ampelisca Control & 3 & 19 & 1 & 0.95 & 0.95 & 0.04 \\
\hline Ampelisca Control & 4 & 20 & 0 & 1.00 & & \\
\hline Ampelisca Control & 5 & 19 & 1 & 0.95 & & \\
\hline
\end{tabular}

(a) Survival based on initial exposure of 20 organisms per replicate.

(b) MDRS Mud Dump Reference Site. 
Table A.2. Water Quality Summary for 10-Day Static Renewal, Benthic Acute Toxicity Test with $A$. abdita, Hackensack River

\begin{tabular}{|c|c|c|c|c|c|c|c|c|c|c|}
\hline \multirow[b]{2}{*}{ Sediment Treatment } & \multicolumn{2}{|c|}{$\begin{array}{c}\text { Temperature } \\
\left({ }^{\circ} \mathrm{C}\right) \\
\end{array}$} & \multicolumn{2}{|c|}{$\mathrm{pH}$} & \multicolumn{2}{|c|}{$\begin{array}{c}\text { Dissolved } \\
\text { Oxygen } \\
\text { (mg/L) }\end{array}$} & \multicolumn{2}{|c|}{$\begin{array}{c}\text { Salinity } \\
(\% \circ)\end{array}$} & \multicolumn{2}{|c|}{$\begin{array}{c}\text { Total } \\
\text { Ammonia } \\
(\mathrm{a}) \\
(\mathrm{mg} / \mathrm{L})\end{array}$} \\
\hline & Min. & Max. & Min. & Max. & Min. & Max. & Min. & Max. & Min. & Max. \\
\hline Acceptable Range: & 18.0 & 22.0 & 7.30 & 8.30 & 4.6 & $N A^{(b)}$ & 28.0 & 32.0 & NA & 20.0 \\
\hline COMP HR & 19.4 & 20.4 & 7.94 & 8.09 & 6.5 & 7.0 & 31.0 & 31.5 & $<1.0$ & 1.4 \\
\hline \multicolumn{11}{|l|}{ Reference } \\
\hline $\mathrm{MDRS}^{(c)}$ & 19.2 & 20.3 & 7.89 & 8.09 & 6.5 & 7.0 & 30.5 & 32.0 & $<1.0$ & $<1.0$ \\
\hline Ampelisca Control & 19.4 & 20.4 & 7.93 & 8.30 & 6.4 & 7.0 & 31.0 & 32.0 & $<1.0$ & $<1.0$ \\
\hline $\begin{array}{l}\text { (b) NA Not applicab } \\
\text { (c) MDRS Mud Dum }\end{array}$ & & & & & & & & & & \\
\hline
\end{tabular}


Table A.3. Results of 96-Hour, Cadmium Reference Toxicant Test with with $A$. abdita, Hackensack River

\begin{tabular}{|c|c|c|c|c|c|c|}
\hline $\begin{array}{c}\text { Cadmium } \\
\text { Conc. mg/L } \\
\end{array}$ & Replicate & Live & $\begin{array}{l}\text { Dead or } \\
\text { Missing }\end{array}$ & $\begin{array}{c}\text { Proportion } \\
\text { Surviving } \\
\end{array}$ & $\begin{array}{c}\text { Mean } \\
\text { Proportion } \\
\text { Surviving }\end{array}$ & $\begin{array}{l}\text { Standard } \\
\text { Deviation }\end{array}$ \\
\hline 0.00 & 1 & 19 & 1 & 0.95 & & \\
\hline 0.00 & 2 & 20 & 0 & 1.00 & 0.98 & 0.03 \\
\hline 0.00 & 3 & 20 & 0 & 1.00 & & \\
\hline 0.19 & 1 & 18 & 2 & 0.90 & & \\
\hline 0.19 & 2 & 19 & 1 & 0.95 & 0.92 & 0.03 \\
\hline 0.19 & 3 & 18 & 2 & 0.90 & & \\
\hline 0.38 & 1 & 15 & 5 & 0.75 & & \\
\hline 0.38 & 2 & 17 & 3 & 0.85 & 0.82 & 0.06 \\
\hline 0.38 & 3 & 17 & 3 & 0.85 & & \\
\hline 0.75 & 1 & 6 & 14 & 0.30 & & \\
\hline 0.75 & 2 & 8 & 12 & 0.40 & 0.35 & 0.05 \\
\hline 0.75 & 3 & 7 & 13 & 0.35 & & \\
\hline 1.50 & 1 & 0 & 20 & 0.00 & & \\
\hline 1.50 & 2 & 0 & 20 & 0.00 & 0.00 & 0.00 \\
\hline 1.50 & 3 & 0 & 20 & 0.00 & & \\
\hline
\end{tabular}

(a) Survival based on initial exposure of 20 organisms per replicate. 
Table A.4. Water Quality Summary for 96-Hour A. abdita Cadmium Reference Toxicant Test, Hackensack River

\begin{tabular}{cccccccccc}
$\begin{array}{c}\text { Cadmium } \\
\begin{array}{c}\text { Concentration } \\
(\mathrm{mg} / \mathrm{L})\end{array}\end{array}$ & $\begin{array}{c}\text { Temperature } \\
\left({ }^{\circ} \mathrm{C}\right)\end{array}$ & \multicolumn{2}{c}{$\mathrm{pH}$} & \multicolumn{3}{c}{$\begin{array}{c}\text { Dissolved } \\
\text { Oxygen } \\
(\mathrm{mg} / \mathrm{L})\end{array}$} & \multicolumn{2}{c}{$\begin{array}{c}\text { Salinity } \\
(\% \circ)\end{array}$} \\
\cline { 2 - 8 } Min. & Max. & Min. & Max. & Min. & Max. & Min. & Max. \\
\hline $\begin{array}{c}\text { Acceptable } \\
\text { Range: }\end{array}$ & 18.0 & 22.0 & 7.30 & 8.30 & 4.6 & NA $^{(\mathrm{a})}$ & 28.0 & 32.0 \\
0.00 & 19.3 & 19.8 & 8.11 & 8.14 & 6.8 & 7.2 & 31.0 & 32.0 \\
0.19 & 19.3 & 19.7 & 8.10 & 8.13 & 7.0 & 7.2 & 31.0 & 32.0 \\
0.38 & 19.4 & 19.8 & 8.07 & 8.12 & 6.9 & 7.2 & 31.0 & 32.0 \\
0.75 & 19.4 & 19.8 & 8.04 & 8.12 & 6.9 & 7.3 & 31.0 & 32.0 \\
1.50 & 19.4 & 19.7 & 7.83 & 8.08 & 6.7 & 7.3 & 31.0 & 32.0
\end{tabular}

(a) NA Not applicable. 
Table A.5. Results of 10-day, Static Renewal, Benthic Acute Toxicity Test with M. bahia, Hackensack River

\begin{tabular}{lcccccc}
$\begin{array}{l}\text { Sediment } \\
\text { Treatment }\end{array}$ & Replicate & Live(a) & $\begin{array}{c}\text { Dead or } \\
\text { Missing }\end{array}$ & $\begin{array}{c}\text { Proportion } \\
\text { Surviving }\end{array}$ & $\begin{array}{c}\text { Mean } \\
\text { Proportion } \\
\text { Surviving }\end{array}$ & $\begin{array}{c}\text { Standard } \\
\text { Deviation }\end{array}$ \\
\hline COMP HR & 1 & 19 & 1 & 0.95 & & \\
COMP HR & 2 & 18 & 2 & 0.90 & & \\
COMP HR & 3 & 19 & 1 & 0.95 & 0.93 & 0.03 \\
COMP HR & 4 & 18 & 2 & 0.90 & & \\
COMP HR & 5 & 19 & 1 & 0.95 & & \\
& & & & & & \\
Reference & 1 & 17 & -3 & 0.85 & & \\
MDRS(1) & 2 & 19 & 1 & 0.95 & & \\
MDRS & 3 & 18 & 2 & 0.90 & 0.91 & 0.04 \\
MDRS & 4 & 19 & 1 & 0.95 & & \\
MDRS & 5 & 18 & 2 & 0.90 & & \\
MDRS & 1 & 18 & 2 & 0.90 & & \\
& 2 & 20 & 0 & 1.00 & & \\
Mysidopsis Control & 1 & 19 & 1 & 0.95 & 0.95 & 0.05 \\
Mysidopsis Control & 2 & 18 & 2 & 0.90 & & \\
Mysidopsis Control & 3 & 4 & 18 & & \\
Mysidopsis Control & 4 & & & & \\
Mysidopsis Control & 5 & 20 & 0 & 1.00 & & -
\end{tabular}

(a) Survival based on initial exposure of 20 organisms per replicate.

(b) MDRS Mud Dump Reference Site. 
Table A.6. Water Quality Summary for 10-Day, Static Renewal, Benthic Acute Toxicity Test with M. bahia, Hackensack River

\begin{tabular}{|c|c|c|c|c|c|c|c|c|c|c|}
\hline \multirow{2}{*}{$\begin{array}{l}\text { Sediment } \\
\text { Treatment }\end{array}$} & \multicolumn{2}{|c|}{$\begin{array}{c}\text { Temperature } \\
\left({ }^{\circ} \mathrm{C}\right)\end{array}$} & \multicolumn{2}{|c|}{$\mathrm{pH}$} & \multicolumn{2}{|c|}{$\begin{array}{l}\text { Dissolved } \\
\text { Oxygen } \\
(\mathrm{mg} / \mathrm{L})\end{array}$} & \multicolumn{2}{|c|}{$\begin{array}{c}\text { Salinity } \\
(\% \circ)\end{array}$} & \multicolumn{2}{|c|}{$\begin{array}{c}\text { Total } \\
\text { Ammonia } \\
(\mathrm{mg} / \mathrm{L})\end{array}$} \\
\hline & Min. & Max. & Min. & Max. & Min. & Max. & Min. & Max. & Min. & Max. \\
\hline Acceptable Range: & 18.0 & 22.0 & 7.30 & 8.30 & 3.0 & $N A^{(b)}$ & 28.0 & 32.0 & NA & 15.0 \\
\hline COMP HR & 19.4 & 20.3 & 7.69 & 7.96 & 5.8 & 7.0 & 30.5 & 32.0 & $<1.0$ & 7.4 \\
\hline \multicolumn{11}{|l|}{ Reference } \\
\hline $\mathrm{MDRS}^{(\mathrm{c})}$ & 19.7 & 20.3 & 7.70 & 8.01 & 5.9 & 7.1 & 30.5 & 32.0 & $<1.0$ & $<1.0$ \\
\hline Mysidopsis control & 19.7 & 20.3 & 7.79 & $8.45^{(d)}$ & 5.8 & 7.0 & 30.5 & 32.0 & $<1.0$ & $<1.0$ \\
\hline $\begin{array}{l}\text { (a) Overlying water } \\
\text { (b) NA Not applicat } \\
\text { (c) MDRS Mud Dur } \\
\text { (d) Data point out of }\end{array}$ & ca & nen & & & & & & & & \\
\hline
\end{tabular}


Table A.7. Results of 96-Hour, Copper Reference Toxicant Test with M. bahia, Hackensack River

\begin{tabular}{|c|c|c|c|c|c|c|}
\hline $\begin{array}{c}\text { Copper } \\
\text { Conc. } \mathrm{mg} / \mathrm{L}\end{array}$ & Replicate & Live $^{(a)}$ & $\begin{array}{l}\text { Dead or } \\
\text { Missing }\end{array}$ & $\begin{array}{c}\text { Proportion } \\
\text { Surviving } \\
\end{array}$ & $\begin{array}{c}\text { Mean } \\
\text { Proportion } \\
\text { Surviving } \\
\end{array}$ & $\begin{array}{l}\text { Standard } \\
\text { Deviation } \\
\end{array}$ \\
\hline 0.0 & 1 & 10 & 0 & 1.00 & & \\
\hline 0.0 & 2 & 10 & 0 & 1.00 & 0.97 & 0.06 \\
\hline 0.0 & 3 & 9 & 1 & 0.90 & & \\
\hline 0.15 & 1 & 8 & 2 & 0.80 & & \\
\hline 0.15 & 2 & 10 & 0 & 1.00 & 0.90 & 0.10 \\
\hline 0.15 & 3 & 9 & 1 & 0.90 & & \\
\hline 0.2 & 1 & 4 & 6 & 0.40 & & \\
\hline 0.2 & 2 & 4 & 6 & 0.40 & 0.37 & 0.06 \\
\hline 0.2 & 3 & 3 & 7 & 0.30 & & \\
\hline 0.3 & 1 & 0 & 10 & 0.00 & & \\
\hline 0.3 & 2 & 1 & 9 & 0.10 & 0.03 & 0.06 \\
\hline 0.3 & 3 & 0 & 10 & 0.00 & & \\
\hline 0.4 & 1 & 0 & 10 & 0.00 & & \\
\hline 0.4 & 2 & 0 & 10 & 0.00 & 0.00 & 0.00 \\
\hline 0.4 & 3 & 0 & 10 & 0.00 & & \\
\hline
\end{tabular}

(a) Survival based on initial exposure of 10 organisms per replicate. 
Table A.8. Water Quality Summary for 96-Hour, Copper Reference Toxicant Test with M. bahia, for Benthic Acute Toxicity Test, Hackensack River

\begin{tabular}{ccccccccc}
$\begin{array}{c}\text { Copper } \\
\begin{array}{c}\text { Concentration } \\
(\mathrm{mg} / \mathrm{L})\end{array}\end{array}$ & $\begin{array}{c}\text { Temperature } \\
\left({ }^{\circ} \mathrm{C}\right)\end{array}$ & \multicolumn{2}{c}{$\mathrm{pH}$} & \multicolumn{3}{c}{$\begin{array}{c}\text { Dissolved } \\
\text { Oxygen } \\
(\mathrm{mg} / \mathrm{L})\end{array}$} & \multicolumn{2}{c}{$\begin{array}{c}\text { Salinity } \\
(\%)\end{array}$} \\
\cline { 2 - 9 } & Min. & Max. & Min. & Max. & Min. & Max. & Min. & Max. \\
\hline $\begin{array}{c}\text { Acceptable } \\
\text { Range: }\end{array}$ & 18.0 & 22.0 & 7.30 & 8.30 & 3.0 & NA $^{(\mathrm{a})}$ & 28.0 & 32.0 \\
0.0 & 19.0 & 19.6 & 7.89 & 8.03 & 6.4 & 7.2 & 31.0 & 32.0 \\
0.15 & 19.0 & 19.6 & 7.82 & 8.00 & 6.6 & 7.3 & 31.0 & 31.5 \\
0.2 & 19.1 & 19.7 & 7.80 & 8.10 & 6.7 & 7.2 & 31.0 & 32.0 \\
0.3 & 19.1 & 19.5 & 7.78 & 8.05 & 6.5 & 7.3 & 31.0 & 32.0 \\
0.4 & 19.1 & 19.5 & 7.74 & 8.09 & 6.8 & 7.3 & 31.0 & 31.5
\end{tabular}

(a) NA Not applicable. 